\title{
Acrocomia aculeata (Jacq.) Lodd. Oil Microencapsulation by Complex Coacervation: Preservation of Bioactive Compounds
}

\author{
Caroline Honaiser Lescano ${ }^{1 *}$, Eliana Janet Sanjinez-Argandoña ${ }^{1}$, Eduardo José de Arruda1, \\ Cândida Aparecida Leite Kassuya ${ }^{2}$, Izabel Cristina Freitas Moraes $^{3}$ \\ ${ }^{1}$ College of Exact Sciences and Technology, Federal University of Grande Dourados, Dourados, Brazil \\ ${ }^{2}$ College of Health Science, Federal University of Grande Dourados, Dourados, Brazil \\ ${ }^{3}$ College of Animal Science and Food Engineering, University of São Paulo, Pirassununga, Brazil \\ Email: carolinehonaiser@gmail.com
}

Received 15 September 2014; revised 10 October 2014; accepted 5 November 2014

Copyright (C) 2014 by authors and Scientific Research Publishing Inc.

This work is licensed under the Creative Commons Attribution International License (CC BY).

http://creativecommons.org/licenses/by/4.0/

(c) (i) Open Access

\section{Abstract}

Acrocomia aculeata (Jacq.) Lodd. shows possibilities for pharmaceutical, food and chemical use. However, its application is limited due to the loss of its bioactive components. Microencapsulation may be an alternative to reduce such problems. A step-by-step optimization approach was used in this work for preservation of bioactive compounds. The applied technique to microencapsulate the Acrocomia aculeata oil was efficient, producing between $64 \%$ and $99 \%$ of microcapsules and $59 \%$ to $97 \%$ of encapsulated oil. In the experimental design, temperature was the parameter that significantly influenced the carotenoids of microcapsules. Complex coacervation helped to preserve carotenoids and the antioxidant activity, and an interaction between the temperature and the content was observed for such preservation.

\section{Keywords}

Microencapsulation, Acrocomia aculeata, Carotenoids, Antioxidant Activity

\section{Introduction}

Acrocomia aculeata (Jacq.) Lodd. is a palm tree belonging to the Arecaceae family [1], popularly known as bo-

*Corresponding author.

How to cite this paper: Lescano, C.H., et al. (2014) Acrocomia aculeata (Jacq.) Lodd. Oil Microencapsulation by Complex Coacervation: Preservation of Bioactive Compounds. Journal of Encapsulation and Adsorption Sciences, 4, 105-113. 
caiuva, macaúba, coco-babão, bacaúva, mocajuba, macaíba, and it is found in tropical regions, occurring abundantly in the Brazilian savanna [2]. Studies on its nutritional composition show that bocaiuva is rich in lipids, carbohydrates and fibers [3]-[5], in addition to contribute source for carotenoids and fatty acids, with an emphasis on $\beta$-carotene in the oil [4] [6].

However, one of the major technological difficulties in relation to oils and bioactive components is their preservation, since most part of these components reacts with heat and oxygen [7]. Among the techniques employed to extend the stability of oils and other bioactive components is microencapsulation [8]. Several techniques have been used to elaborate microcapsules, such as: complex coacervation [9], spray drying [10], ionic gelation [11], among others.

The coacervation method has been employed due to the simple procedures involved to obtain the microcapsules, which protect the encapsulated material from adverse conditions, such as, $\mathrm{pH}$, light, temperature, enzymes, among others. This technique also enables the controlled release of encapsulated compounds [12]-[14].

Considering that many of the bioactive compounds present in the fruit from Acrocomia aculeata are susceptible to degradation and thus, to the loss of interesting properties and biological activities, the microencapsulation technique may favor the preservation of such compounds and facilitate their application in food, pharmacological, cosmetic and other products.

\section{Experimental}

\subsection{Materials}

The ripe fruits from Acrocomia aculeata (Jacq.) Lodd. were collected at Foundation MS, in the district of Mara-

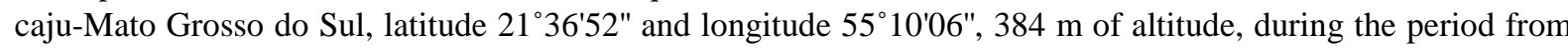
December 2011 to January 2012. The pulp was previously dehydrated at $40^{\circ} \mathrm{C}$ in a tray dryer (NG Científica) with a $0.5 \mathrm{~m} / \mathrm{s}$ airflow for $72 \mathrm{~h}$. The oil was extracted from the pulp by cold pressing in an expeller-type press (Ecirtec MPE-40P). After their extraction, the oils were centrifuged at $1500 \mathrm{rpm}$ for $15 \mathrm{~min}$. As the encapsulating agents, gelatin (Fluka Analytical) and gum arabic (Vetec) were used.

\subsection{Microencapsulation}

The microcapsules were produced according to the method described by Alvim and Grosso [15], using full factorial design (Table 1). The microcapsules were produced using as wall material gelatin and gum arabic solutions at a concentration of $2.5 \mathrm{~g} \cdot \mathrm{mL}^{-1}$. To create the content, the Acrocomia aculeata oil was used, at the following concentrations: $5 \mathrm{~g}, 7.5 \mathrm{~g}$ and $10 \mathrm{~g} \cdot \mathrm{mL}^{-1}$, where the gelatin solution at $40^{\circ} \mathrm{C}, 60^{\circ} \mathrm{C}$ and $50^{\circ} \mathrm{C}$ was mixed with the Acrocomia aculeata oil (content) and homogenized in Ultraturrax (Marconi MA-102) for 1 min (at a

Table 1. Yield and efficiency of the microencapsulation and size of the Acrocomia aculeata oil microcapsules obtained by complex coacervation, under different processing conditions.

\begin{tabular}{|c|c|c|c|c|c|c|}
\hline \multicolumn{4}{|c|}{ Variables } & \multicolumn{3}{|c|}{ Responses } \\
\hline Test & Content (g) & Temperature $\left({ }^{\circ} \mathrm{C}\right)$ & Speed (rpm) & Encapsulation Efficiency (\%) & Yield (\%) & Size $(\mu \mathrm{m})$ \\
\hline 1 & $5(-1)$ & $40(-1)$ & $12,000(-1)$ & $68.44 \pm 1.00^{\mathrm{a}}$ & $69.55 \pm 8.46^{\mathrm{ac}}$ & $238.51^{\mathrm{a}}$ \\
\hline 2 & $10(1)$ & $40(-1)$ & $12,000(-1)$ & $89.92 \pm 2.14^{\mathrm{bc}}$ & $94.65 \pm 7.06^{\text {bd }}$ & $384.99^{\mathrm{a}}$ \\
\hline 3 & $5(-1)$ & $60(1)$ & $12,000(-1)$ & $86.41 \pm 2.77^{\mathrm{b}}$ & $82.24 \pm 2.74^{\mathrm{ab}}$ & $277.14^{\mathrm{a}}$ \\
\hline 4 & $10(1)$ & $60(1)$ & $12,000(-1)$ & $59.77 \pm 1.37^{\mathrm{e}}$ & $88.25 \pm 5.92^{\text {bd }}$ & $382.65^{\mathrm{a}}$ \\
\hline 5 & $5(-1)$ & $40(-1)$ & $18,000(1)$ & $87.67 \pm 2.14^{b}$ & $90.05 \pm 4.72^{\text {bd }}$ & $439.18^{\mathrm{a}}$ \\
\hline 6 & $10(1)$ & $40(-1)$ & $18,000(1)$ & $76.36 \pm 1.53^{f}$ & $64.50 \pm 1.89^{c}$ & $639.57^{b}$ \\
\hline 7 & $5(-1)$ & $60(1)$ & $18,000(1)$ & $97.86 \pm 1.29^{d}$ & $95.89 \pm 3.15^{\mathrm{d}}$ & $265.91^{\mathrm{a}}$ \\
\hline 8 & $10(1)$ & $60(1)$ & $18,000(1)$ & $93.72 \pm 1.92^{\mathrm{cd}}$ & $96.61 \pm 0.46^{\mathrm{d}}$ & $320.37^{\mathrm{a}}$ \\
\hline 9 & $7.5(0)$ & $50(0)$ & $15,000(0)$ & $94.19 \pm 3.46^{\mathrm{cd}}$ & $99.02 \pm 1.21^{\mathrm{d}}$ & $320.49^{\mathrm{a}}$ \\
\hline
\end{tabular}

Equal letters on the same column are not significantly different among themselves on a 5\% level on Tukey's Test. 
speed of 12,000, 15,000 and 18,000 rpm). The emulsion was added to the gum arabic solution at $40^{\circ} \mathrm{C}, 60^{\circ} \mathrm{C}$ and $50^{\circ} \mathrm{C}$, and then, $400 \mathrm{~mL}$ of deionized water was added at the same temperature $\left(40^{\circ} \mathrm{C}, 60^{\circ} \mathrm{C}\right.$ and $\left.50^{\circ} \mathrm{C}\right)$, keeping the entire process under magnetic stirring (Marconi MA-085), $\mathrm{pH}$ was adjusted to reach $\mathrm{pH} 4.0$, using $\mathrm{HCl} 2.5$ and $0.1 \mathrm{~mol} \cdot \mathrm{L}^{-1}$ solutions. After the $\mathrm{pH}$ adjustment, the solutions containing the microcapsules were cooled down, using an ice bath to gradually cool down the system, kept under slow and constant magnetic stirring, up to the point the temperature reached approximately $10^{\circ} \mathrm{C}$. After the microcapsules were decanted, the system was kept in the refrigerator. All the assays were conducted in triplicates.

\subsection{Encapsulation Efficiency}

The encapsulation efficiency (EE) of Acrocomia aculeata oil was determined by quantifying the oil contained by the microcapsules in relation to the original amount used to produce the particles, expressed as percentage Equation (1). The amount of content encapsulated by the produced coacervated microparticles, according to the full factorial design, was determined by the total lipid content, according to the Bligh and Dyer method, with some adaptations [16].

$$
E E(\%)=\frac{\text { oil }(\mathrm{g}) / \text { particle in drybase }(\mathrm{g})}{\text { oil }(\mathrm{g}) / \text { total initial solid }(\mathrm{g})} \times 100
$$

\subsection{Process Yield}

The microencapsulation process yield was calculated through the weight of the obtained phases, after a minimum resting period of $12 \mathrm{~h}$ in the refrigerator at $4^{\circ} \mathrm{C}$. After coacervation, the produced and precipitated capsules were centrifuged $(15,000 \mathrm{rpm} / 5 \mathrm{~min})$, separated and weighted. The moisture content of the microparticles was determined using a gravimetric method in an incubator with air circulation according to the AOAC [17]. The microencapsulation process yield was calculated as the percentage of precipitated dry material in relation to the initial dry mass (sum of the mass of polymers in dry base and the oil content used).

\subsection{Morphology and Size of Microcapsules}

The morphology and size of microcapsules were observed by optical microscopy (Carl Nikon Eclipse-200), assisted by the Image Pro Plus 4.0 software to obtain the images. To calculate the diameter, 150 particles were measured for each formulation using the same software previously mentioned [13].

\subsection{Determining the Antioxidant Activity Using the ABTS• Method}

The determinations as to the ability to eliminate the ABTS • (2,2'-Azino-bis(3-ethylbenzothiazoline-6-sulfonic acid) diammonium salt) free radicals were conducted according to the methodology described by Rufino et al. [18]. A standard curve was prepared using Trolox (6-Hydroxy-2,5,7,8-tetramethylchromane-2-carboxylic acid) as the standard at different concentrations $\left(100,500,1000,1500\right.$ and $\left.2000 \mu \mathrm{M} \cdot \mathrm{L}^{-1}\right)$. The reaction solutions containing $30 \mu \mathrm{L}$ of the extract of microcapsules and $3 \mathrm{~mL}$ of reagent (potassium persulfate $2.45 \mathrm{mM} \cdot \mathrm{L}^{-1}$ with ABTS $7 \mathrm{mM} \cdot \mathrm{L}^{-1}$ ) were incubated at $30^{\circ} \mathrm{C}$ for $6 \mathrm{~min}$, and the reading were made by a spectrophotometer UV-VIS (Varian-Cary 50) at a $734 \mathrm{~nm}$ absorbance. The inhibition concentration was calculated in relation to the Trolox standard curve. The results were expressed in $\mu \mathrm{g}$ Trolox/g of the sample. The analyses were conducted in triplicates.

\subsection{Total Polyphenol Content}

The total polyphenol contents from the samples were analyzed according to the spectrophotometry method by Folin-Ciocateau described by George et al. [19] using gallic acid as the standard. In test tubes, $0.5 \mathrm{~mL}$ of the extract from microcapsules were diluted in $2.5 \mathrm{~mL}$ of the aqueous solution from the Folin-Ciocalteau's reagent (10\%), adding $2.0 \mathrm{~mL}$ of sodium carbonate aqueous solution (7.5\%), which were incubated in water bath at $50^{\circ} \mathrm{C}$ for $15 \mathrm{~min}$, and then cooled down using an ice bath; the absorbance readings were performed by a spectrophotometer (Varian-Cary 50) at $760 \mathrm{~nm}$. Results were expressed as gallic acid equivalent in $\mathrm{mg} \cdot \mathrm{g}^{-1} \mathrm{of}$ the sample. 


\subsection{Total Carotenoids}

The total carotenoids were determined according to the method described by Carvalho, et al. [20] between $1.5 \mathrm{~g}$ and $5 \mathrm{~g}$ of the sample was to extract the carotenoids, successive macerations were applied using $50 \mathrm{~mL}$ of refrigerated acetone. The extracts were evaluated through spectrometry using a $450 \mathrm{~nm}$ absorbance. In order to calculate the total carotenoid concentration (Ct), Equation (2) was used.

$$
C t\left(\frac{\mu \mathrm{g}}{\mathrm{g}}\right)=\frac{A b s \times V \times 10^{4}}{E_{1 \mathrm{~cm}}{ }^{1 \%} \times m_{\text {sample }}}
$$

where, $A b s$ is the absorbance in the maximum absorbance peak, $\mathrm{V}$ is the sample's final volume $(\mathrm{mL}), m_{\text {sample }}$ is the sample mass $(\mathrm{g}), E_{1 \mathrm{~cm}}{ }^{1 \%}$ is the extinction coefficient $(\beta$-carotene $=2592$ in petroleum ether).

\subsection{Statistical Analysis}

The results of the characterization of microcapsules, and the evaluation of bioactive compounds were submitted to variance analysis (ANOVA), and to compare the means, Tukey's test $(p \leq 0.05)$ was conducted, using the Statistic software (Statsoft).

\section{Results and Discussion}

\subsection{Obtaining the Microcapsules}

Complex coacervation occurs under extremely specific conditions for polymeric peers have a balance of produced loads, among other factors, such as by the fine-tuning of $\mathrm{pH}$, obtaining a high yield of microcapsules. Thus, the coacervate is formed as a precipitate, and this precipitate is responsible for capturing the oil during the coacervated phase [21].

In order to promote a more efficient coacervation, the temperature, homogenization speed and morphology variables were evaluated. The study was conducted using samples obtained at different core concentrations (5, 7.5 and $10 \mathrm{~g} \cdot \mathrm{mL}^{-1}$ ), since the formulations offer a greater separation into phases, determined by greater sediment mass and a less turbid supernatant. The formation of a large amount of coacervated mass does not necessarily mean that the oil was encapsulated, and it is necessary to evaluate the encapsulation efficiency.

\subsection{Encapsulation Efficiency}

Applying the complex coacervation technique to microencapsulate the Acrocomia aculeata oil was efficient, producing around $59.77 \%$ to $97.86 \%$ of microcapsules (Table 1). The encapsulation's efficiency corroborated with this yield. Wieland-Berghausen et al. [22] reported that the active-polymeric material proportion was an important factor for the encapsulation's efficiency. By reducing the content's concentration, the chance of the polymers to cover the material's droplets is increased, which allows greater efficiency. In addition, they verified that the efficiency increases in more viscous systems in relation to the encapsulated material. That explains the high efficiency observed to form the Acrocomia aculeata oil microcapsules.

\subsection{Process Yield}

Applying the complex coacervation technique to microencapsulate the Acrocomia aculeata oil was efficient, producing about $64 \%$ to $99 \%$ of microcapsules (Table 1 ). The evaluation of the results obtained by this design indicated that the following variables: content, temperature and speed, synergic ally influenced the process yield, as observed in tests 7, 8 and 9, showing the importance of the evaluated factors. However, the concentration of the content during the emulsion and the interactions between the studied variables showed no significant effect $(p \leq 0.05)$ on the encapsulation's efficiency.

\subsection{Morphology and Size of the Microcapsules}

The average size of the moisture coacervated microcapsules containing Acrocomia aculeata oil determined by optical microscopy is shown in Table 1. The size of the microcapsules were between 238.51 and $384.99 \mu \mathrm{m}$, which is expected for microcapsules produced by complex coacervation, according to Favaro-Trindade et al. [23] 
they may vary from 1 to $500 \mu \mathrm{m}$. However, the formulation of test 6 (Table 1), it can be observed that the average diameter was $639.57 \mu \mathrm{m}$; this difference may be due to the process conditions, which includes the emulsion preparation conditions and the cooling speed, physical and chemical characteristics of the wall materials, as well as the superficial tension and the hydrophobicity degree of the content material used. In the literature, average diameters were described varying from 39 up to $680 \mu \mathrm{m}$ for particles obtained by complex coacervation [24] [25].

Figure 1 show two micrographs corresponding to the tests with maximum yield (Test 9, Figure 1(a)) and minimum yield of the microcapsules (Test 6, Figure 1(b)). The Acrocomia aculeata oil microcapsules obtained with wall material constituted by gelatin and gum arabic, under the content $(7.5 \mathrm{~g})$, temperature $\left(50^{\circ} \mathrm{C}\right)$ and homogenization speed $(15,000 \mathrm{rpm})$ conditions showed a round shape. The wall material and the presence of the oil in the core may be clearly observed (Figure 1(a)). Mendanha et al. [26] for the encapsulation of hydrolyzed casein with pectin as wall material, also obtained a round shape. Under conditions with lower temperature $\left(40^{\circ} \mathrm{C}\right)$ and greater content (10 g), the size of the microcapsules was significantly higher (Test 6), and the shape varied (Figure 1(b)).

Favaro-Trindade et al. [23] indicate that the size of the microcapsules produced by complex coacervation, using gelatin and gum arabic as wall material, is influenced by several factors, such as stirring rate, viscosity of the solution, content/polymer, and amount of water. In this study, the temperature significantly influenced the size of the microcapsule. Figure 2(a) and Figure 2(b) show that the lower the amount of content (oil), the smaller will be the size of the microcapsule.

\subsection{Antioxidant Activity}

The bioactive components may undergo changes during the microencapsulation process due to the temperature and the homogenization speed. In this content, the total phenol and carotenoids contents and the antioxidant activity of the samples were determined in the microencapsulated material from all tests (Table 2).

For the antioxidant activity ABTS•, significant effects were observed for the content-temperature and temperature-speed interactions. This behavior may be explained by the temperature's action on the degradation process, by activating some oxidative reactions [27], and on the content's distribution, which may be strongly associated with the stability of the emulsions formed by different combinations between the variables [25].

\subsection{Total Polyphenols}

When determining the phenolic compounds in the produced microcapsule, a significant effect of the interaction of variables on the formulations was not observed, as shown in Table 2. This observation corroborates with the results found by Nori et al. [13] for the microencapsulation of propolis extract, where the researchers verified that there was no influence of temperature on the phenolic compounds.

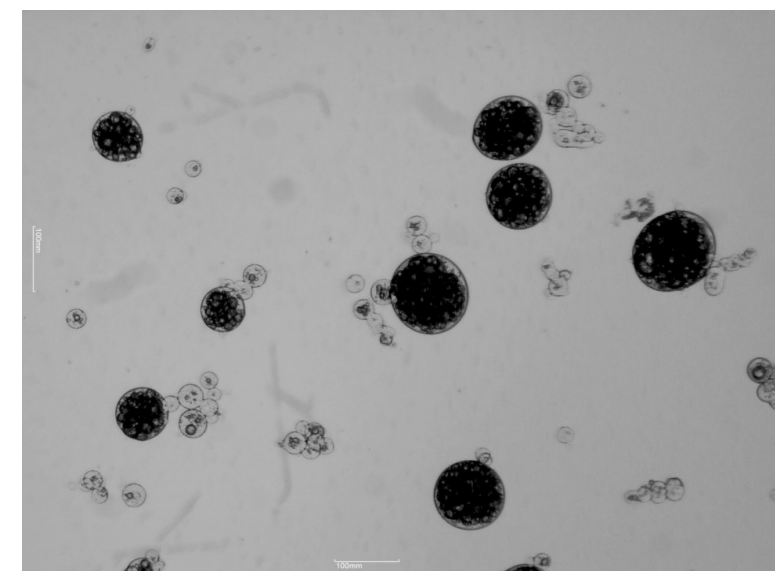

(a)

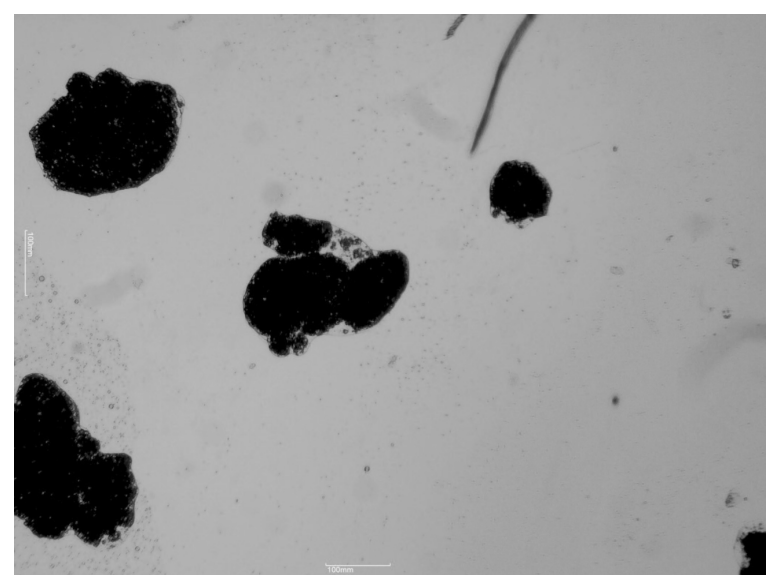

(b)

Figure 1. Micrographs of the Acrocomia aculeata oil microcapsules coacervated with gum arabic and gelatin. Test 9 (a) and Test 6 (b). 


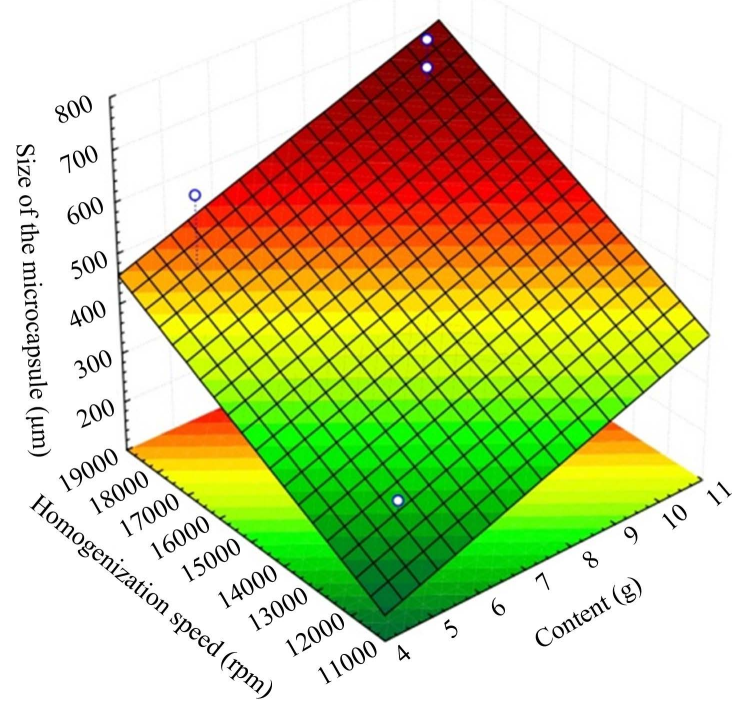

(a)

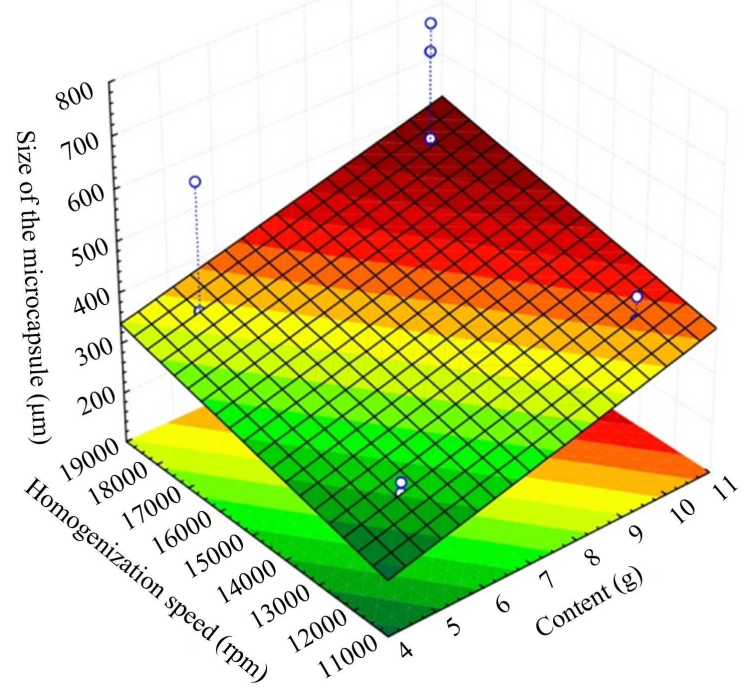

(b)

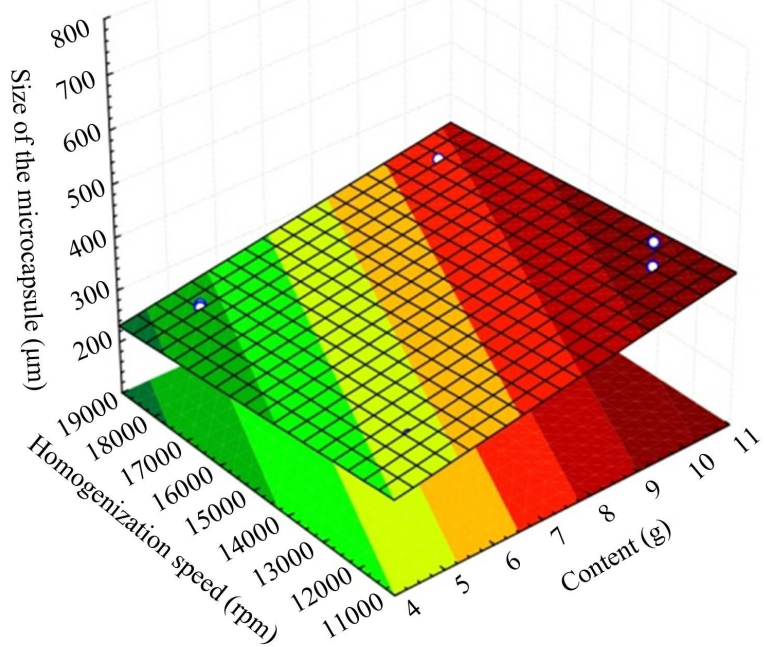

(c)

Figure 2. Influence of temperature on the average size of microcapsules. (a) Temperature at $40^{\circ} \mathrm{C}$; (b) Temperature at $50^{\circ} \mathrm{C}$; (c) Temperature at $60^{\circ} \mathrm{C}$.

\subsection{Total Carotenoids}

The effect of the content, temperature and homogenization speed factors in the carotenoids in the microcapsules is shown in Table 2. The significant variables were homogenization speed and the temperature-homogenization speed interaction. High temperatures may contribute with a considerable loss of carotenoids, and its increase is reported as one of the causes of degradation of this bioactive compound [28], justifying its influence in this study.

The results corroborate with those found by Ying-Qv and Jiang [29], in the microencapsulation of the lutein carotenoid by complex coacervation, where a reduction in the retention rate of lutein happened with the increase in temperature. It was observed that the temperature had noticeable effects on the encapsulated active ingredient. The interaction between the homogenization speed and temperature on the carotenoids is also verified. This fact 
Table 2. Antioxidant activity using the ABTS - method. Total polyphenol and total carotenoids for the Acrocomia aculeata oil microcapsules obtained by complex coacervation, under different processing conditions.

\begin{tabular}{|c|c|c|c|c|c|c|}
\hline \multicolumn{4}{|c|}{ Variables } & \multicolumn{3}{|c|}{ Responses } \\
\hline Test & Content (g) & Temperature $\left({ }^{\circ} \mathrm{C}\right)$ & Speed (rpm) & $\begin{array}{l}\text { Antioxidant Activity } \\
\text { ( } \mu \text { g Trolox/g sample) }\end{array}$ & $\begin{array}{c}\text { Total polyphenol } \\
\text { (mg gallic acid } \mathrm{g}^{-1} \text { sample) }\end{array}$ & $\begin{array}{c}\text { Carotenoids } \\
(\mu \mathrm{g} / \mathrm{g} \text { sample) }\end{array}$ \\
\hline 1 & $5(-1)$ & $40(-1)$ & $12000(-1)$ & $2.64 \pm 0.39^{\mathrm{ab}}$ & $1.85 \pm 0.13^{\mathrm{a}}$ & $148.70 \pm 5.80^{\mathrm{ab}}$ \\
\hline 2 & $10(1)$ & $40(-1)$ & $12000(-1)$ & $1.52 \pm 0.18^{\mathrm{ac}}$ & $1.37 \pm 0.29^{\mathrm{a}}$ & $212.24 \pm 56.98^{\mathrm{bcd}}$ \\
\hline 3 & $5(-1)$ & $60(1)$ & $12000(-1)$ & $1.39 \pm 0.12^{\mathrm{c}}$ & $1.47 \pm 0.35^{\mathrm{a}}$ & $174.45 \pm 30.72^{\text {abcd }}$ \\
\hline 4 & $10(1)$ & $60(1)$ & $12000(-1)$ & $2.69 \pm 0.35^{\mathrm{b}}$ & $1.50 \pm 0.21^{\mathrm{a}}$ & $85.35 \pm 10.33^{\mathrm{a}}$ \\
\hline 5 & $5(-1)$ & $40(-1)$ & $18000(1)$ & $1.38 \pm 0.15^{c}$ & $1.41 \pm 0.24^{\mathrm{a}}$ & $198.42 \pm 59.11^{\text {abcd }}$ \\
\hline 6 & $10(1)$ & $40(-1)$ & $18000(1)$ & $1.53 \pm 0.97^{\mathrm{ac}}$ & $1.44 \pm 0.08^{\mathrm{a}}$ & $127.28 \pm 24.82^{\mathrm{abd}}$ \\
\hline 7 & $5(-1)$ & $60(1)$ & $18000(1)$ & $1.89 \pm 0.05^{\mathrm{abc}}$ & $1.30 \pm 0.22^{\mathrm{a}}$ & $178.71 \pm 31.60^{\mathrm{abcd}}$ \\
\hline 8 & $10(1)$ & $60(1)$ & $18000(1)$ & $2.86 \pm 0.04^{\mathrm{b}}$ & $1.65 \pm 0.32^{\mathrm{a}}$ & $253.71 \pm 13.43^{\mathrm{c}}$ \\
\hline 9 & $7.5(0)$ & $50(0)$ & $15000(0)$ & $2.60 \pm 0.34^{\mathrm{ab}}$ & $1.52 \pm 0.43^{\mathrm{a}}$ & $229.29 \pm 21.73^{\mathrm{cd}}$ \\
\hline
\end{tabular}

Equal letters on the same column are not significantly different among themselves on a 5\% level on Tukey’s Test.

may be related to stirring, where shearing occurs, creating smaller coacervated droplets, in addition to the incorporation of air bubbles during stirring, since according to Rodriguez-Amaya et al. [28], the presence of oxygen is one of the factors that contribute for the degradation of carotenoids.

\section{Conclusion}

The results presented in this work show that it is possible to microencapsulate Acrocomia aculeata oil by complex coacervation technique in order to preserve bioactive compounds. The yield process and encapsulation efficiency were in the range from $64 \%$ to $99 \%$ of microcapsules and from $59 \%$ to $97 \%$ of encapsulated oil, respectively. This process preserves the carotenoids and antioxidant activity of the oil. Through experimental design, it was possible to verify an interaction between temperature and the oil content in the preservation of carotenoids; moreover, the temperature was the parameter that significantly influenced the morphology of the microcapsules. Furthermore, these results enable the use of the microcapsules of the fruits oil (Acrocomia aculeata) as a natural food additive.

\section{Acknowledgements}

Brazilian Federal Agency for Support and Evaluation of Graduate Education-CAPES for the financial help. The authors thank Espaço da Escrita-Coordenadoria Geral da Universidade-UNICAMP-for the language services provided.

\section{References}

[1] Siles, L., Cela, J. and Munné-Bosch, S. (2013) Vitamin E Analyses in Seeds Reveal a Dominant Presence of Tocotrienols over Tocopherols in the Arecaceae Family. Phytochemistry, 95, 207-214. http://dx.doi.org/10.1016/j.phytochem.2013.07.008

[2] Hiane, P.A., Baldasso, P.A., Marangoni, S. and Macedo, M.L.R. (2006) Chemical and Nutritional Evaluation of Kernels of Bocaiuva, Acrocomia aculeata (Jacq.) Lodd. Ciência e Tecnologia de Alimentos, 26, 683-689. http://dx.doi.org/10.1590/S0101-20612006000300031

[3] Bora, P.S. and Rocha, R.V.M. (2004) Macaiba Palm: Fatty and Amino Acids Composition of Fruits. Ciência e Tecnologia de Alimentos, 4, 158-162.

[4] Ramos, M.I.L., Ramos-Filho, M.M., Hiane, P.A., Braga-Neto, J.A. and Siqueira, E.M.A. (2008) Qualidade nutricional da polpa da bocaiuva Acrocomia aculeata (Jacq.) Lodd. Ciência e Tecnologia de Alimentos, 28, 90-94. http://dx.doi.org/10.1590/S0101-20612008000500015 
[5] Coimbra, M.C. and Jorge, N. (2011) Proximate Composition of Guariroba (Syagrus oleracea), Jerivá (Syagrus romanzoffiana) and Macaúba (Acrocomia aculeata) Palm Fruits. Food Research International, 44, 2139-2142. http://dx.doi.org/10.1016/j.foodres.2011.03.032

[6] Ramos, M.I., Siqueira, E.A., Isomura, C.C., Barbosa, A.M.J. and Arruda, S.F. (2007) Bocaiuva (Acrocomia aculeata (Jacq.) Lodd) Improved Vitamin A Status in Rats. Journal Agricultural and Food Chemistry, 55, 3186-3190. http://dx.doi.org/10.1021/jf063305r

[7] Rodriguez-Amaya, D.B. (2010) Quantitative Analysis, in Vitro Assessment of Bioavailability and Antioxidant Activity of Food Carotenoids-A Review. Journal of Food Composition and Analysis, 23, 726-740. http://dx.doi.org/10.1016/j.jfca.2010.03.008

[8] Suave, J., Dall’agnol, E.C., Pezzin, A.P.T., Silva, D.A.K., Meier, M.M. and Soldi, V. (2006) Microencapsulação: Inovação em diferentes áreas. Revista Saúde e Ambiente, 7, 12-20.

[9] Xiao, J.-X., Yu, H.-Y. and Jian, Y. (2011) Microencapsulation of Sweet Orange Oil by Complex Coacervation with Soyben Protein Isolate/Gum Arabic. Food Chemistry, 125, 1267-1272. http://dx.doi.org/10.1016/j.foodchem.2010.10.063

[10] Tonon, R.V., Grosso, C.R.F. and Hubinger, M.D. (2011) Influence of Emulsion Composition and Inlet Air Temperature on the Microencapsulation of Flaxseed Oil by Spray Drying. Food Research International, 44, 282-289. http://dx.doi.org/10.1016/j.foodres.2010.10.018

[11] Yoo, S.Y., Song, Y.B., Chang, P.S. and Lee, H.G. (2006) Microencapsulation of $\alpha$-Tocopherol Using Sodium Alginate and Its Controlled Release Properties. Journal of Biological Macromolecules, 38, 25-30. http://dx.doi.org/10.1016/j.ijbiomac.2005.12.013

[12] Kralovec, J.A., Zhang, S., Zhang, W. and Barrow, J.C. (2011) A Review of the Process in Enzymatic Concentration and Microencapsulation of Omega-3 Rich Oil from Fish and Microbial Sources. Food Chemistry, 131, 639-644. http://dx.doi.org/10.1016/j.foodchem.2011.08.085

[13] Nori, M.P., Favarro-Trindade, C.S., Alencar, S.M., Thomazini, M., Balieiro, J.C.C. and Castillo, C.J.C. (2011) Microencapsulation of Propolis Extract by Complex Coacervation. LWT-Food Science and Technology, 44, 429-435. http://dx.doi.org/10.1016/j.lwt.2010.09.010

[14] Ubbink, J. and Krüger, J. (2006) Physical Approaches for the Delivery of Active Ingredients in Foods. Trends in Food Science and Technology, 17, 244-25. http://dx.doi.org/10.1016/j.tifs.2006.01.007

[15] Alvim, I.D. and Grosso, C.R.F. (2010) Microparticles Obtained by Complex Coacervation: Influence of the Type of Reticulation and the Drying Process on the Release of the Core Material. Ciência e Tecnologia de Alimentos, 30, 10691076. http://dx.doi.org/10.1590/S0101-20612010000400036

[16] Bueno, C.M., Alvim, I.D., Koberstein, T.C.R.D., Portela, M.C. and Grosso, C. (2011) Production of Tilapia Skin Gelatin and Its Use in the Production of Micro-Particles Containing Salmon Oil. Brazil Journal of Food Technology, 14, 65-73.

[17] AOAC (2000) Official Methods of Analysis of the AOAC. 17th Edition, Association of Official Analytical Chemists.

[18] Rufino, M.S.M., Alves, R.E., Brito, E.S., Pérez-Jiménez, J., Saura-Calixto, F. and Mancini-Filho, J. (2010) Bioactive Compounds and Antioxidant Capacities of 18 Non-Traditional Tropical Fruits from Brazil. Food Chemistry, 121, 996 1002. http://dx.doi.org/10.1016/j.foodchem.2010.01.037

[19] George, S., Pierre, B., Alter, P. and Amiot, M.J. (2005) Rapid Determination of Polyphenols and Vitamina C in PlantDerived Products. Journal of Agricultural Food Chemistry, 53, 1370-1373. http://dx.doi.org/10.1021/jf048396b

[20] Carvalho, L.M.J., Gomes, P.B., Godoy, R.L.O., Pacheco, S. Monte, P.H.F., Carvalho, J.L.V., et al. (2012) Total Carotenoid Content, $\alpha$-Carotene and $\beta$-Carotene, of Landrace Pumpkins (Cucurbita moschata Duch): A Preliminary Study. Food Research International, 47, 337-340. http://dx.doi.org/10.1016/j.foodres.2011.07.040

[21] Nakagawa, K. and Nagao, H. (2012) Microencapsulation of Oil Droplets Using Freezing-Induced Gelatin-Acacia Complex Coacervation. Colloids and Surfaces A: Physicochemical and Engineering Aspects, 411, 129-139. http://dx.doi.org/10.1016/j.colsurfa.2012.07.010

[22] Wieland-Berghausen, S., Schote, U., Frey, M. and Schmidt, F. (2002) Comparison of Microencapsulation Techniques for the Water-Soluble Drugs Nitenpyram and Clomipramine HCl. Journal of Controlled Release, 85, 35-43. http://dx.doi.org/10.1016/S0168-3659(02)00269-9

[23] Favaro-Trindade, C.S., Pinho, S.C. and Rocha, G.A. (2008) Revisão: Microencapsulação de Ingredientes Alimentícios. Revista Brasileira de Tecnologia de Alimentos, 11, 103-112.

[24] Builders, P.F., Kunle, O.O., Okpaku, L.C., Builders, M.I., Attama, A.A. and Adikwu, M.U. (2008) Preparation and Evaluation of Mucinated Sodium Alginate Microparticles for Oral Delivery of Insulin. European Journal of Pharmaceutics and Biopharmaceutics, 70, 777-783. http://dx.doi.org/10.1016/j.ejpb.2008.06.021

[25] Prata, A.S., Menu, C.T., Leydet, A., Trigo, J.R. and Grosso, C.R.F. (2008) Encapsulation and Release of a Fluorescent 
Probe, Khusimyl Dansylate, Obtained from Vetiver Oil by Complex Coacervation. Flavour and Fragrance Journal, 23, 7-15. http://dx.doi.org/10.1002/ffj.1845

[26] Mendanha, D.V., Ortiz, S.E.M., Favaro-Trindade, C.S., Mauri, A., Monterrey-Quintero, E.S. and Thomazini, M. (2009) Microencapsulation of Casein Hydrolysate by Complex Coacervation with SPI/Pectin. Food Research International, 42, 1099-1104. http://dx.doi.org/10.1016/j.foodres.2009.05.007

[27] Voz, P., Faas, M.M., Spasojevic, M. and Sikkema, J. (2010) Encapsulation for Preservation of Functionality and Targeted Delivery of Bioactive Food Components. International Dairy Journal, 20, 292-302. http://dx.doi.org/10.1016/j.idairyj.2009.11.008

[28] Rodriguez-Amaya, D.B., Kimura, M., Godoy, H.T. and Amaya-Farfan, J. (2008) Updated Brazilian Database on Food Carotenoids: Factors Affecting Carotenoids Composition. Journal of Food Composition and Analysis, 21, 445-446. http://dx.doi.org/10.1016/j.jfca.2008.04.001

[29] Qv, X.-Y., Zeng, Z.-P. and Jiang, J.-G. (2011) Preparation of Lutein Microencapsulation by Complex Coacervation Method and Its Physicochemical Properties and Stability. Food Hydrocolloids, 25, 1596-1603. http://dx.doi.org/10.1016/j.foodhyd.2011.01.006 
Scientific Research Publishing (SCIRP) is one of the largest Open Access journal publishers. It is currently publishing more than 200 open access, online, peer-reviewed journals covering a wide range of academic disciplines. SCIRP serves the worldwide academic communities and contributes to the progress and application of science with its publication.

Other selected journals from SCIRP are listed as below. Submit your manuscript to us via either submit@scirp.org or Online Submission Portal.
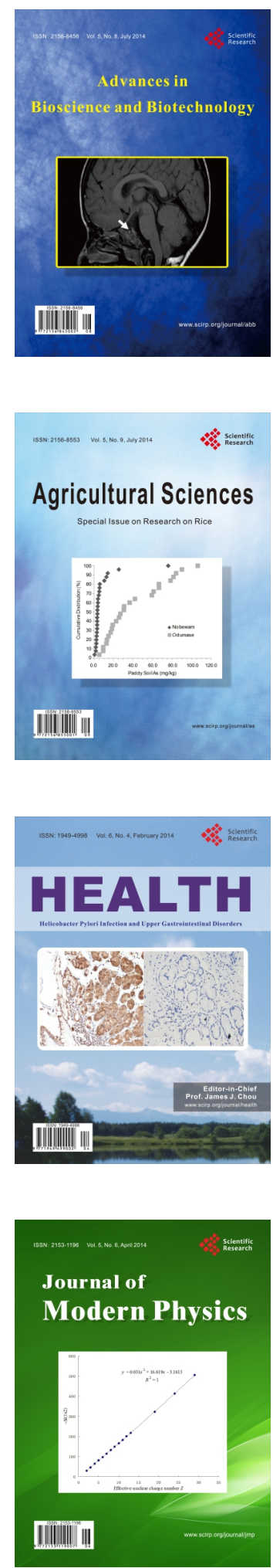
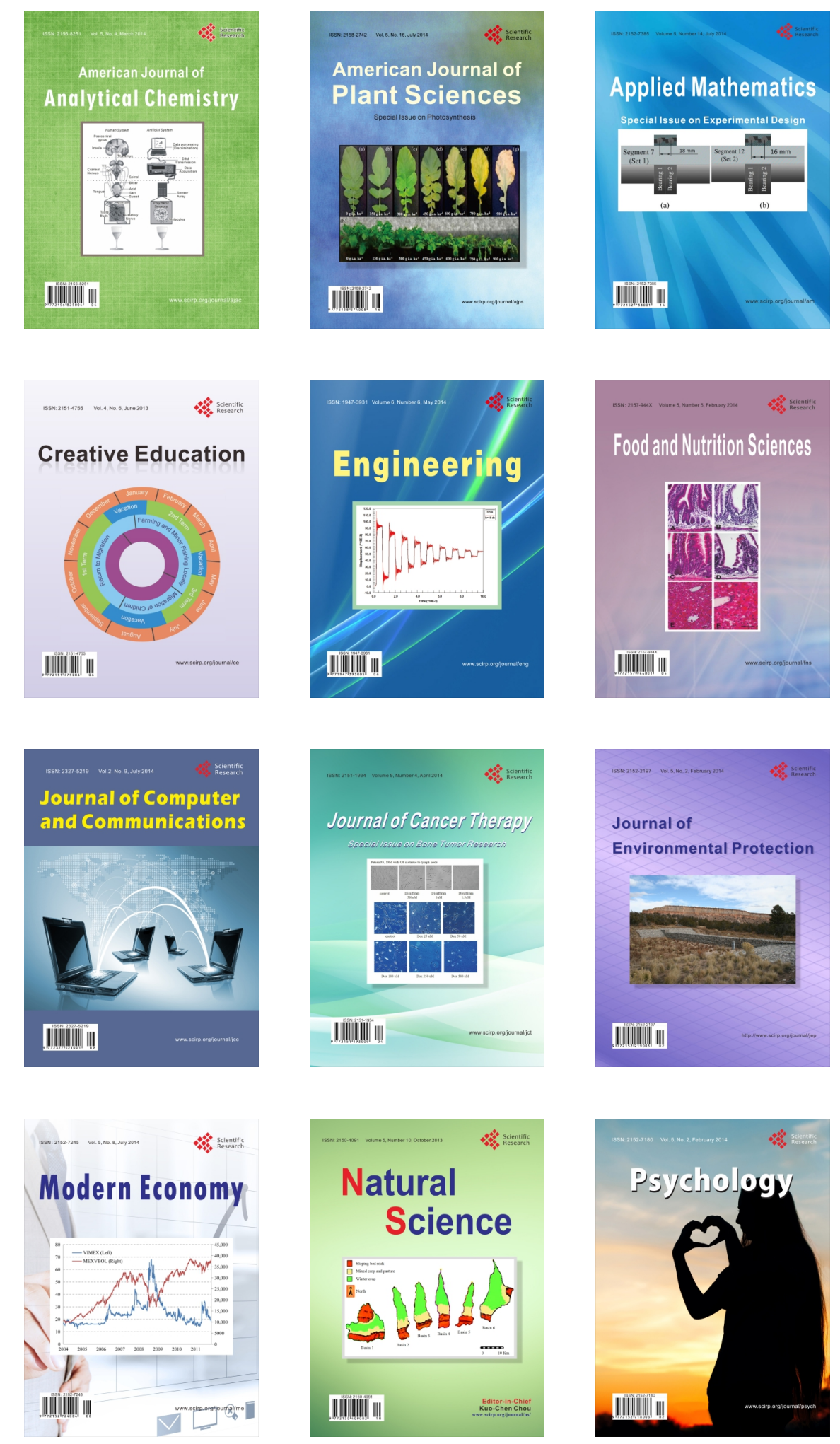